\title{
Bailing out the Titanic with a Thimble
}

\author{
Steve Keen \\ School of Economics \& Finance \\ University of Western Sydney \\ Locked Bag 1797, \\ Penrith 1797, NSW, Australia \\ (email:s.keen@uws.edu.au)
}

The now commonplace observation in the media that this financial crisis is 'the worst since the Great Depression' may appear to be hyperbole to many academic economists. It is not-if anything, it may understate the scale of the crisis.

Ever since Milton Friedman's Monetary History of the United States (Friedman and Schwartz, 1971), neoclassical economists - including the current Chairman of the Federal Reserve, Ben Bernanke (Bernanke, 2002A) - have asserted that the Great Depression was caused by poor monetary policy by the then Federal Reserve. ${ }^{1}$ So much for that theory: today's stark reality should make it unarguable that the real cause of Depression-scale financial crises is excessive private debt accumulated during a preceding speculative bubble - which accords with the 'debt-deflation' hypothesis first developed by Irving Fisher, and perfected by Hyman Minsky, rather than Milton's tale of errant regulators.

The true measure of how big this financial crisis is compared to the Great Depression is therefore the ratio of private debt to nominal GDP, since this ratio of dollars to dollars per year tells us how many years of current output would be needed to repay outstanding debt. On this metric, the USA and Australia entered the current crisis with substantially more debt than prior to the onset of the Great Depression. The USA's debt to GDP ratio was $275 \%$ of GDP at the beginning of 2007, versus $175 \%$ at the end of 1929. The comparable ratios for Australia were $177 \%$ at the beginning of 2008 , versus $65 \%$ at the end of 1929 (see Figure 1). ${ }^{2}$

Added to this is the qualitative change in the nature of debt. The most exotic of Roaring Twenties era debt was probably margin lending; today we have added to that:

1 'Let me end my talk by abusing slightly my status as an official representative of the Federal Reserve. I would like to say to Milton and Anna: Regarding the Great Depression. You're right, we did it. We're very sorry. But thanks to you, we won't do it again.' (Bernanke 2002A).

2 The Australian ratio is derived by adding Credit data in the RBA Statistical Bulletin table D02Hist to selected series for bond issuance in D04Hist, on RBA advice that all 'Long-term non-government securities issued in Australia' (Column K in D04Hist) and some short term bonds (particularly asset-backed securities) are not recorded in D02Hist. This data series only began in 1992, so data prior to this date may understate the level of debt. However it is also the case that the private bond market expanded dramatically in the 1980s, so the comparison of debt including securities today to the pre-1940 debt is still warranted. 
Figure 1: Sources for Debt Data: US Census and FRB Flow of Funds; RBA Bulletin Tables D02 and D04; (Battellino 2007, Kent and Fisher 1999)

Private Debt to GDP Ratios

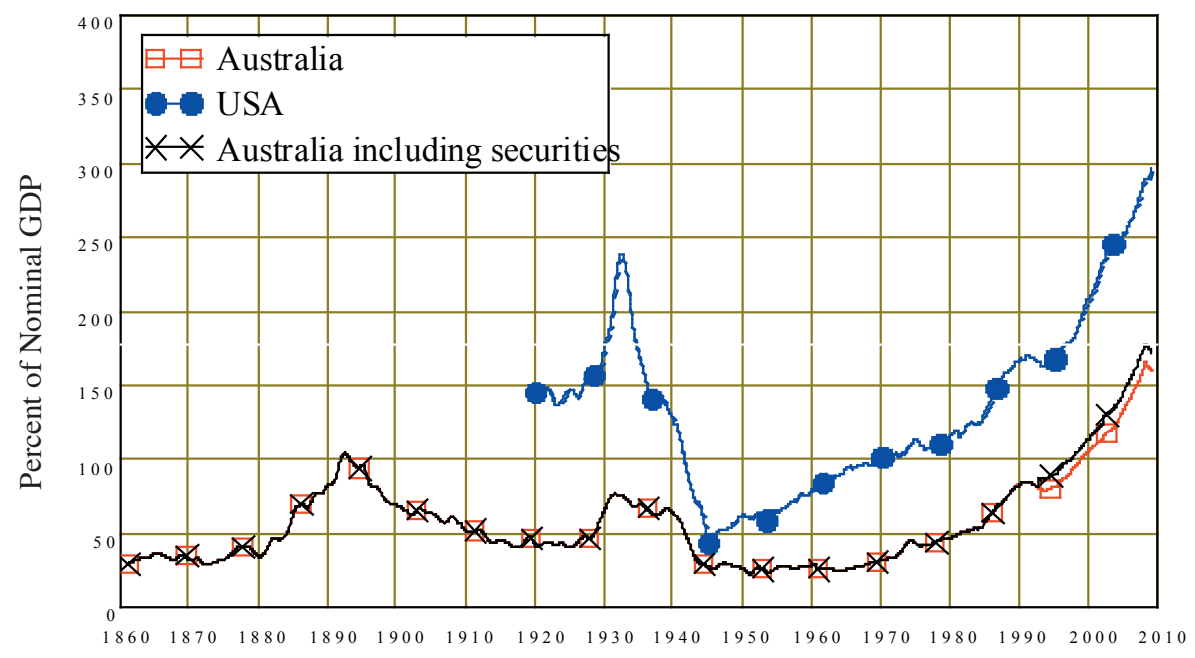

- A kitchen soup of derivative instruments with a gross value of US\$683 trillion as at June $2008,{ }^{3}$ and a net value that is an unknowable factor of how many counterparties go bankrupt. These are clearly not the benign risk-spreading instruments of conventional finance theory, but the 'financial weapons of mass destruction' of which Warren Buffett warned;

- The peculiarly American deviant of 'Adjustable Rate Mortgages', where a low 'teaser' rate on a fixed rate mortgage applies for a short period (up to five years), after which the rate resets to a higher commercial rate, AND the gap between the two rates is capitalised onto the outstanding debt during the teaser period. The crisis was triggered by 2.8 million subprime loans with an average value of $\$ 183,000,62 \%$ of which were ARMs, and $70 \%$ of which have already reset; in the wings await another 2.2 million Alt-A loans with an average value of $\$ 321,000,53 \%$ of which are ARMs and $54 \%$ of which still await resetting; ${ }^{4}$

- The unquantifiable off-balance sheet activities of financial institutions; and

- The junk bond activities of private equity firms.

The unwinding of all these financial esoterica will add to the underlying debt. As well as no doubt requiring future economic historians to revise upwards today's recorded debt levels, the momentum of these debt instruments will also ensure that debt - and bankruptcies - will continue to rise even as economic activity falters.

The greatest amplifier of the debt burden during a Depression, however, is deflation. The US's debt to GDP ratio rose another 60 percent after 1930, not because of increased borrowing, but

3 See http://www.bis.org/statistics/otcder/dt1920a.csv.

4 See http://www.newyorkfed.org/regional/subprime.html. 
because falling output and prices increased the real burden of debt even as borrowers managed (by design or via bankruptcy) to reduce debt in nominal terms (see Figures 2 and 3).

Figure 2: Source US Census

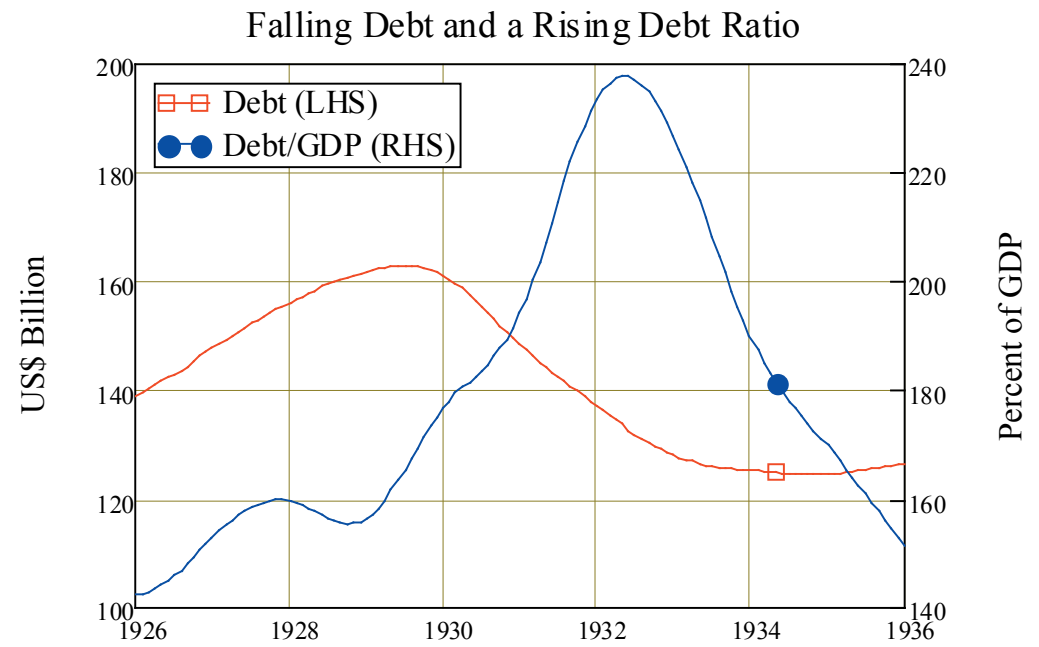

Fisher's characterisation of this phenomenon, that 'the more debtors pay, the more they owe' ${ }^{5}$ deserves the moniker of 'Fisher's Paradox'.

Figure 3: Source BLS

(ftp://ftp.bls.gov/pub/special.requests/cpi/cpiai.txt)

USA Annual Inflation Rate, 1926-1936

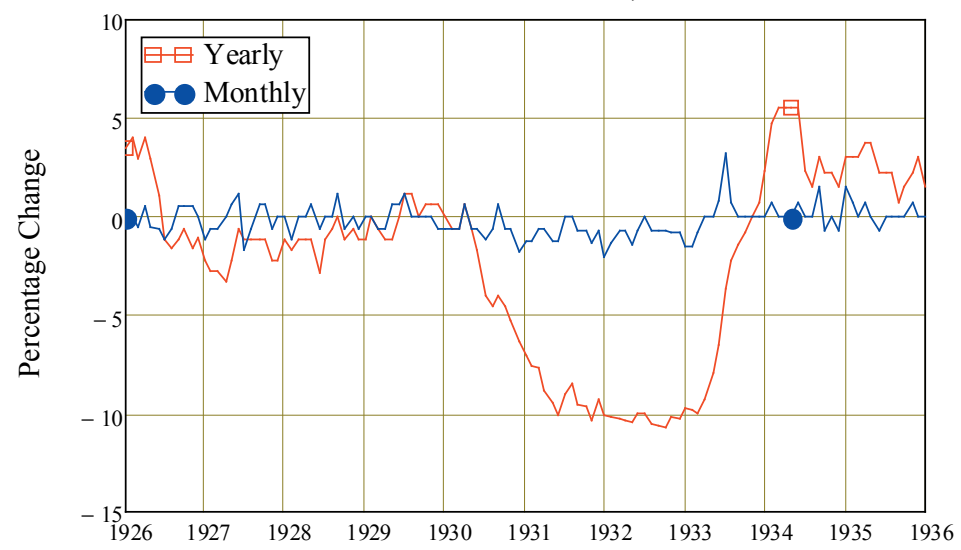

5 Then, the very effort of individuals to lessen their burden of debts increases it, because of the mass effect of the stampede to liquidate in swelling each dollar owed. Then we have the great paradox which, I submit, is the chief secret of most, if not all, great depressions: The more the debtors pay, the more they owe. The more the economic boat tips, the more it tends to tip. It is not tending to right itself, but is capsizing.', Fisher 1933 p. 344 
This is clearly the nightmare that keeps Ben Bernanke awake and at the metaphorical printing press, and it is already with us in the monthly data. November's figure of a $1.9 \%$ fall in the CPI was the steepest since 1932, and the second steepest fall on record, while as of December 2008, the USA had experienced five consecutive months of falling prices. The lagged annual rate of inflation is now barely above zero (see Figure 4).

Figure 4: Source BLS

(ftp://ftp.bls.gov/pub/special.requests/cpi/cpiai.txt)

USA Inflation Rate, 2005-Now

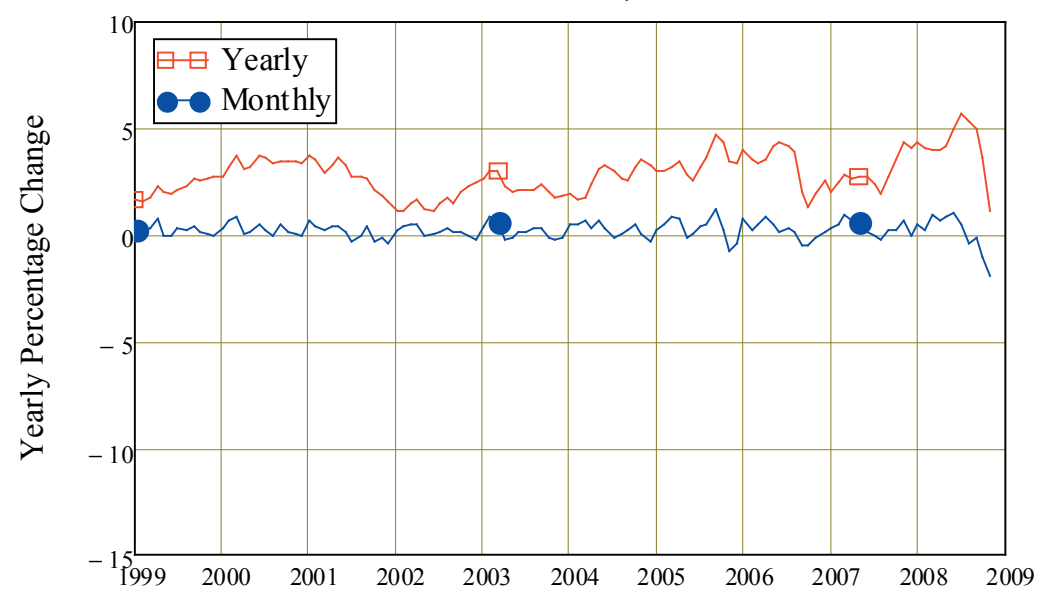

Figure 5: Source: Federal Reserve

(http://www.federalreserve.gov/releases/h3/hist/h3hist1.txt)

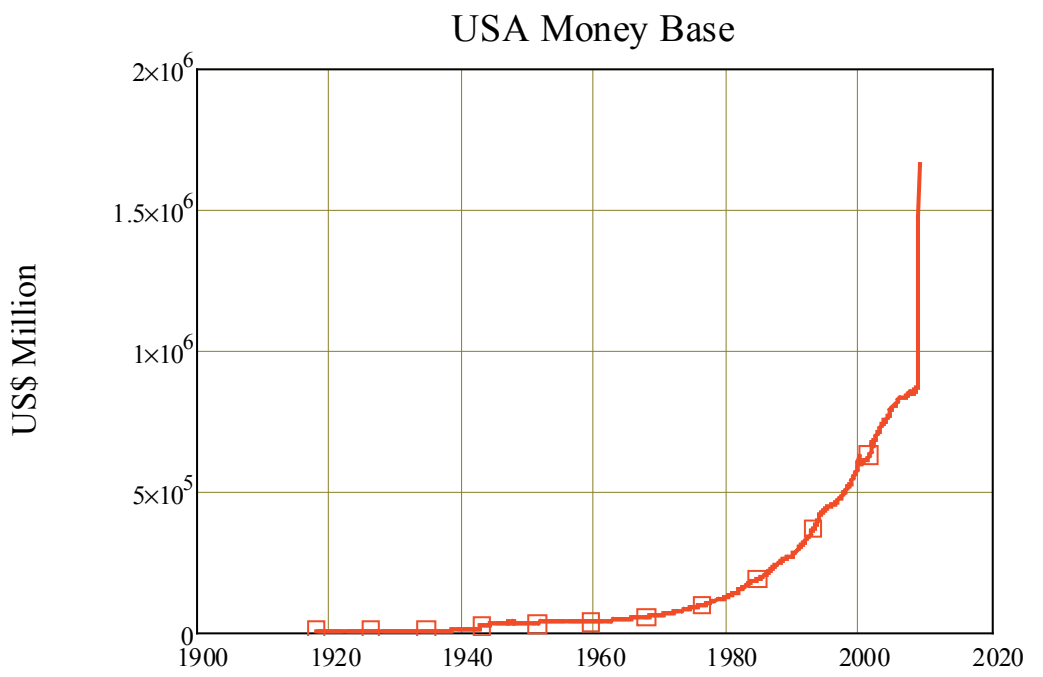


The current crisis thus has the two prerequisites for a Depression identified by Fisher: excessive debt and falling prices. The one positive that may stand in the way of a Depression is a government sector that, in contrast to 1929, is aware of the dangers of a Depression, and determined to do everything in its power to stop it. To this end, the last US government undertook numerous bailouts, while the Obama administration is planning a fiscal stimulus of the order of US\$1 trillion. In monetary policy, the Federal Reserve has dropped its target rate to a range between 0.25 percent and zero, and it is 'printing money' - increasing base money.

The latter in particular is breathtaking - nothing of this scale has ever been attempted before. In a mere four months, Bernanke has doubled the USA's monetary base. He is clearly putting to the test his oft-quoted belief, that 'If we do fall into deflation, however, we can take comfort that the logic of the printing press example must assert itself, and sufficient injections of money will ultimately always reverse a deflation' (Bernanke 2002). ${ }^{6}$

From the perspective of conventional macroeconomics - whether old Keynesian, or neoclassical 'new Keynesian' - monetary actions of this scale should lead to a substantial rise in the money supply, and then in either output or prices, as the 'money multiplier' weaves its magic and amplifies the amount of money in circulation relative to the quantity of goods. However, as well as having reached the zero bound on official interest rates - with little impact on actual lending rates - it seems that Bernanke's quantitative easing is pushing on Keynes's monetary string. The 'money multipliers' have collapsed - to the point that the Money Base now exceeds M1 (see Figure 6 and Figure 7).

Figure 6: Source: Federal Reserve (http://www.federalreserve.gov/releases/h3/hist/h3hist1.txt)

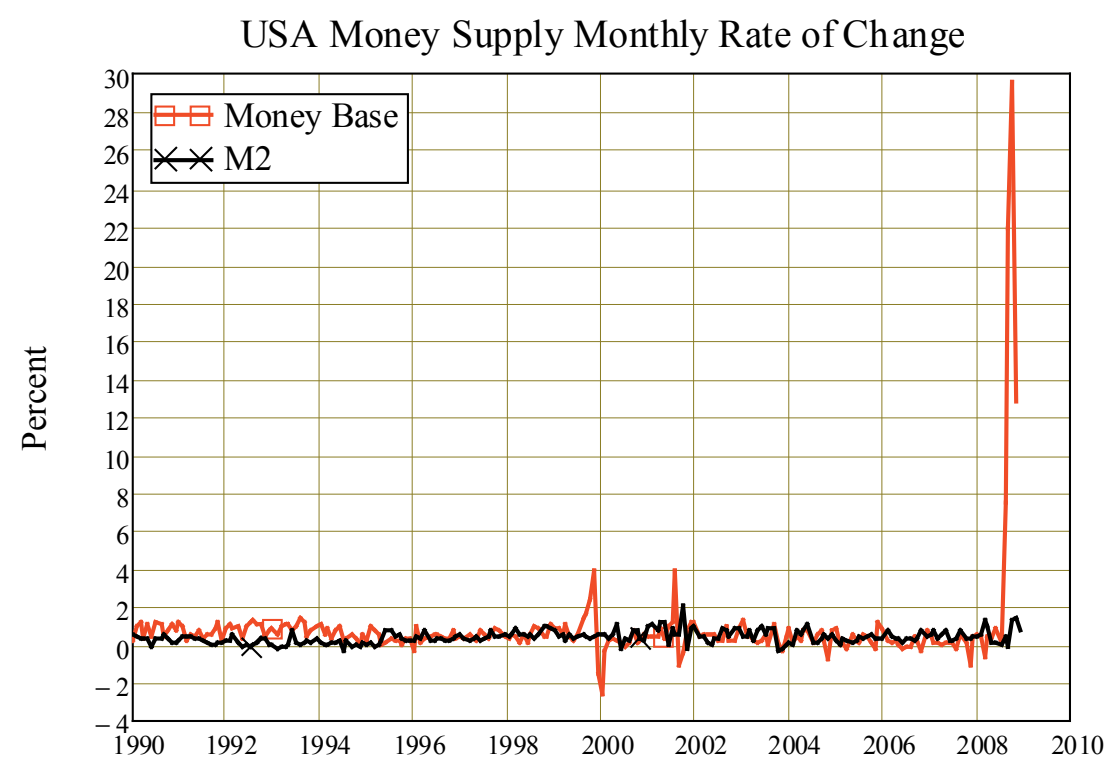

6 This statement won him the moniker of 'Helicopter Ben', even though it was Milton Friedman who first modelled money creation as if it were manna dropped from a heavenly procession of helicopters. 
Figure 7: Source: Federal Reserve (http://www.federalreserve.gov/releases/h3/hist/h3hist1.txt)

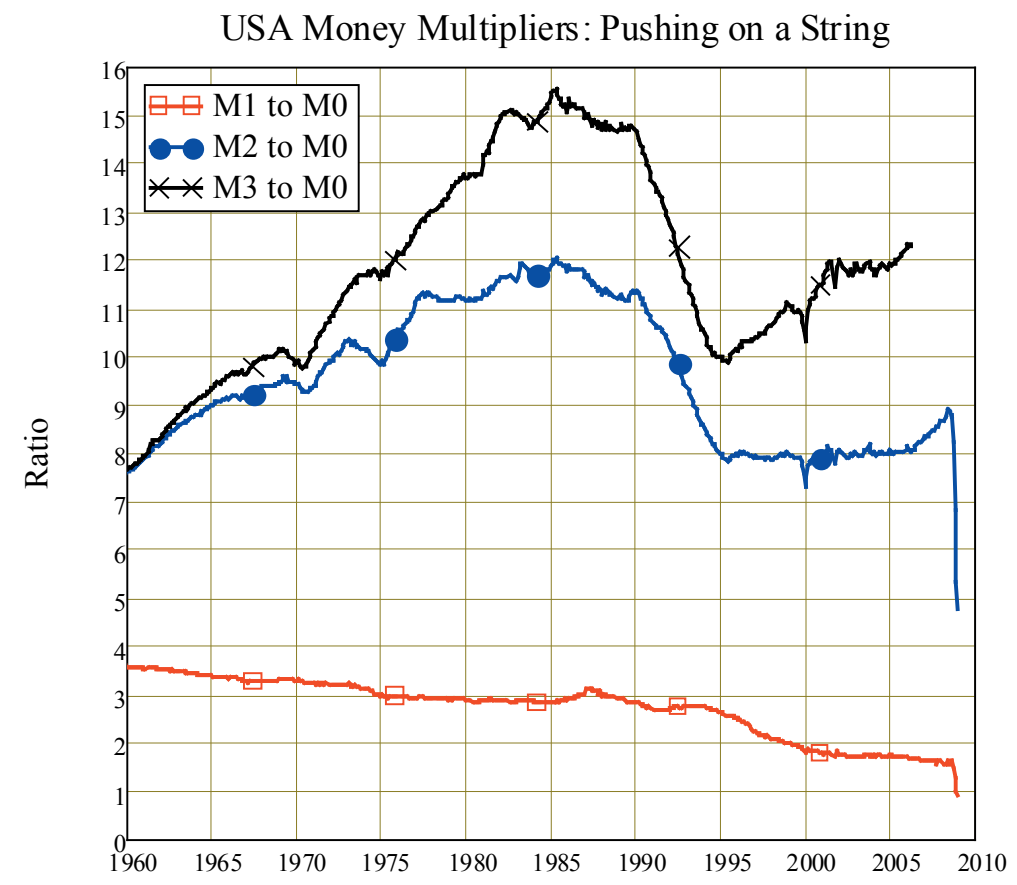

The dramatic increase in Base Money has therefore had literally no effect on the amount of money in circulation to date. It will only do so if, over time, banks lend additional money. However, for the conventional money multiplier analysis of credit creation to work as textbook economics argues - so that the creation of new money would equal a stable money multiplier times the injection of base money - an inconceivable further increase in America's private debt levels would be required. If the pre-Crunch M2 to M0 ratio were to be restored, M2 would have to rise by $86 \%$. If the increase in debt simply matched the increase in M2 (the ratio of private debt to $\mathrm{M} 2$ was 5.5:1 prior to the crisis; see Figure 8), private debt would rise by almost US $\$ 7$ trillion. This is hardly likely in a country that is now justifiably obsessed with de-leveraging. It is therefore more likely that the attempt to prevent deflation via quantitative easing will fail to cause inflation.

Bernanke's dilemma is that he is living in a Minskian world while perceiving it through Friedmanite eyes. Having ignored the run up of debt and the asset bubbles it financed during the long boom (in his 2002 paean to Milton Friedman, Bernanke specifically criticised the 1920s Fed for its "antispeculative' policy tightening of 1928-29', Bernanke 2002A; see also Bernanke and Gertler 2001), the dynamics of debt are now swamping his attempts to mount a Monetarist rescue. As financial institutions retreat from lending, the collapse in credit-created money will overwhelm Bernanke's attempts to expand fiat money.

I have a related expectation for the impact of planned fiscal stimuli. The policies being undertaken now and mooted by Obama are being championed by everyone from 'born again 
Figure 8: Source: Federal Reserve Flow of Funds (http://www.federalreserve.gov/releases/z1)

Ratio of Private Debt to M2

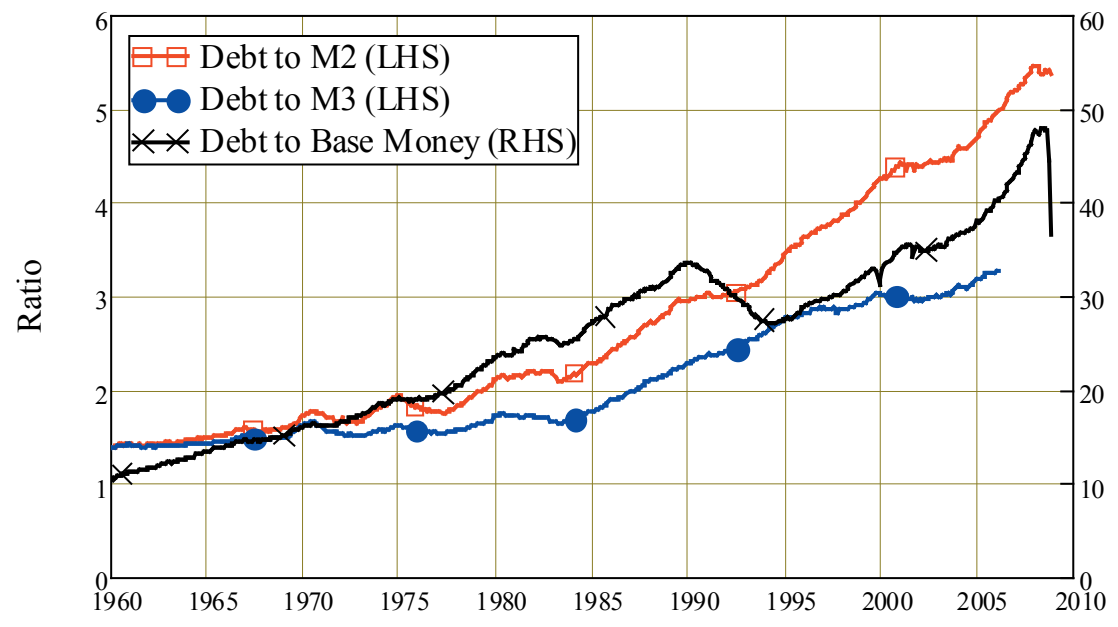

Keynesian' free-marketers to old style Keynesians. They even accord with Minsky's belief that counter-cyclical government spending and central bank 'lender of last resort' actions can stabilise an unstable economy.

However, though I am proudly Minskian in my economics, I expect the bailouts to fail. Minsky, I fear, was an optimist. The basis for this opinion is the feeling that, even though Minsky gave Ponzi finance a key role in his 'Financial Instability Hypothesis', he did not foresee the extent to which misguided government action would rescue Ponzi financing from itself, and therefore renew it, in the name of systemic stabilisation.

So rescued by every Federal Reserve intervention since Greenspan's bailout of Wall Street in the 1987 Crash, Ponzi behaviour kept adding a mass of unproductive debt - debt that simply financed asset price speculation rather than productive investment - to the already accumulated level of debt. As a result, the level of debt far exceeds the money supply, and debt has risen far faster than GDP. Now, as borrowers desperately attempt to reduce debt, the reduction in debt-financed spending will far outweigh any government fiscal stimulus.

From this perspective, each apparent economic recovery after a debt-induced crisis was really a re-ignition of the fundamentally Ponzi lending that had caused the preceding crisis - but with a change in the sector that took on the debt. After the 1980s speculative bubbles on Wall Street (and in commercial property development, with its lending to the Charles Keatings of the world), we had the DotCom Bubble with its lending to highly unprofitable Internet startups, followed by the Subprime Bubble and its lending to individuals with impaired credit histories. ${ }^{7}$ It is inconceivable that any other sector of the American public can be enticed (or trusted) to

7 And many other financial crises in between with their own rescues, such as that of Long Term Capital Management. 
take on more debt, and thus to cause another Ponzi recovery. After all, the only group below the now exhausted Subprimes in credit-worthiness are already in gaol.

Equally, private debt has now reached such extreme levels that I do not believe the economic crisis that its unwinding will cause can be countered by conventional fiscal and monetary measures. To quantify this assertion, it is necessary to take a monetary perspective on the factors determining aggregate demand, and see it as the sum of nominal GDP plus the change in debt. ${ }^{8}$ When debt is small relative to nominal GDP, the contribution from change in debt to demand can safely be ignored; but as debt rises relative to GDP, the proportion of aggregate expenditure that is debt-financed can become substantial. Given the relative volatility of changes in debt to the GDP, it is feasible that changes in debt levels-especially private debt-will dominate changes in economic activity.

Figure 9: Sources: RBA Statistical Bulletin Tables D02 and G12

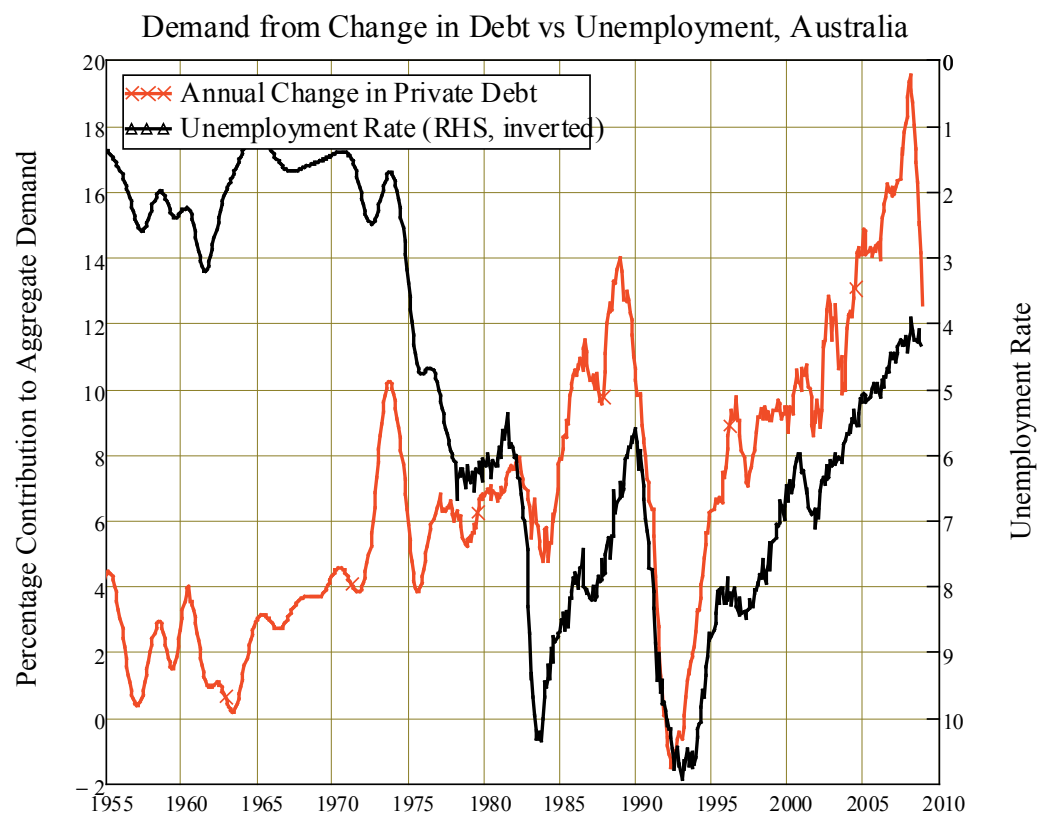

This is evident in the negative correlation between the contribution that change in debt makes to aggregate expenditure ${ }^{9}$ and the unemployment rate, which is illustrated visually in Figure 9 (the unemployment scale is inverted) and via a simple unlagged correlation coefficient in Figure 10. The correlation over the entire time period is trivial and slightly positive. But as time goes on, and the change in debt goes from contributing to just $4 \%$ of aggregate expenditure to almost $20 \%$, the correlation becomes strongly negative.

8 Because both income and additional debt are spent on net asset purchases as well as commodities, this perspective unavoidably entangles spending on asset markets as well as on goods and services.

Defined as the change in debt, divided by the sum of the change in debt and nominal GDP. 


\section{Figure 10}

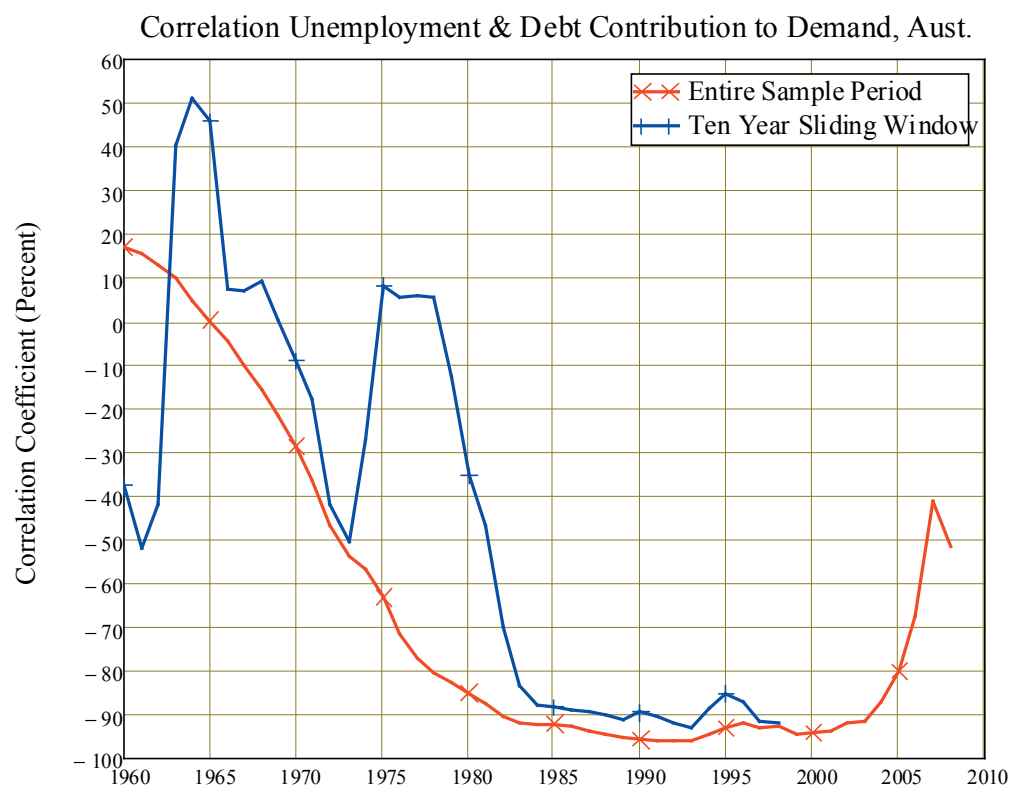

A similar correlation is apparent in the US data (Figure 9 and Figure 11), where the growth of private debt contributed to over $25 \%$ of aggregate expenditure at its peak, and where the fall in debt has already been marked - as has the rise in unemployment.

Figure 11: Sources: Federal Reserve Flow of Funds and BEA NIPA (http://www.bea.gov/national/nipaweb)

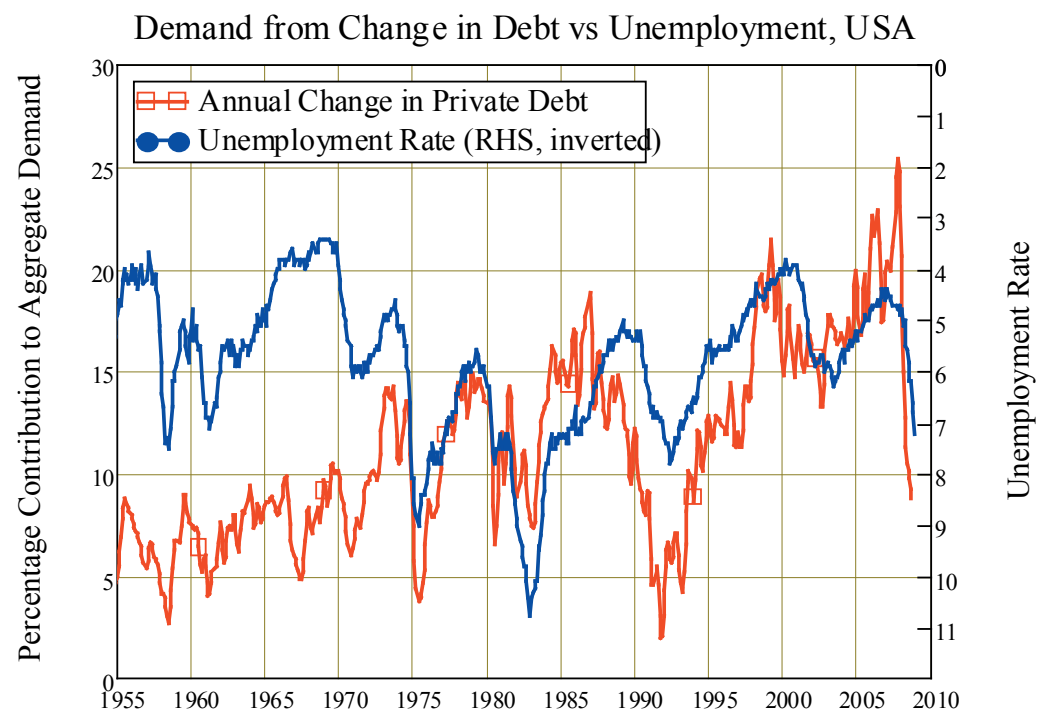


The causal relation behind the correlation is the impact of de-leveraging on economic activity. In the USA's case, at its peak the annual growth in private debt added US $\$ 4.7$ trillion to aggregate spending, compared to an annual GDP of US\$14 trillion. The immediate impact of the cessation of private debt growth is thus a 25 percent reduction in aggregate spending.

If the private sector then succeeded in reducing aggregate debt levels by as little as 5 percent per annum, that would reduce aggregate spending by US\$2.7 trillion in the first year. ${ }^{10}$ This far exceeds the size of the fiscal stimulus mooted by the Obama administration.

Summarising my empirical argument, the scale of private debt in the USA means (a) that the deleveraging process already underway in the USA will swamp government attempts to stimulate demand; and (b) that it is highly unlikely that another 'Ponzi' rescue of the American economy can be affected via stimulating private borrowing; and (c) the collapse in credit creation will easily outweigh even Bernanke's dramatic attempt to boost the money supply by increasing Base Money. A Depression is therefore highly likely.

\section{Figure 12}

Correlation Unemployment \& Debt Contribution to Demand, USA

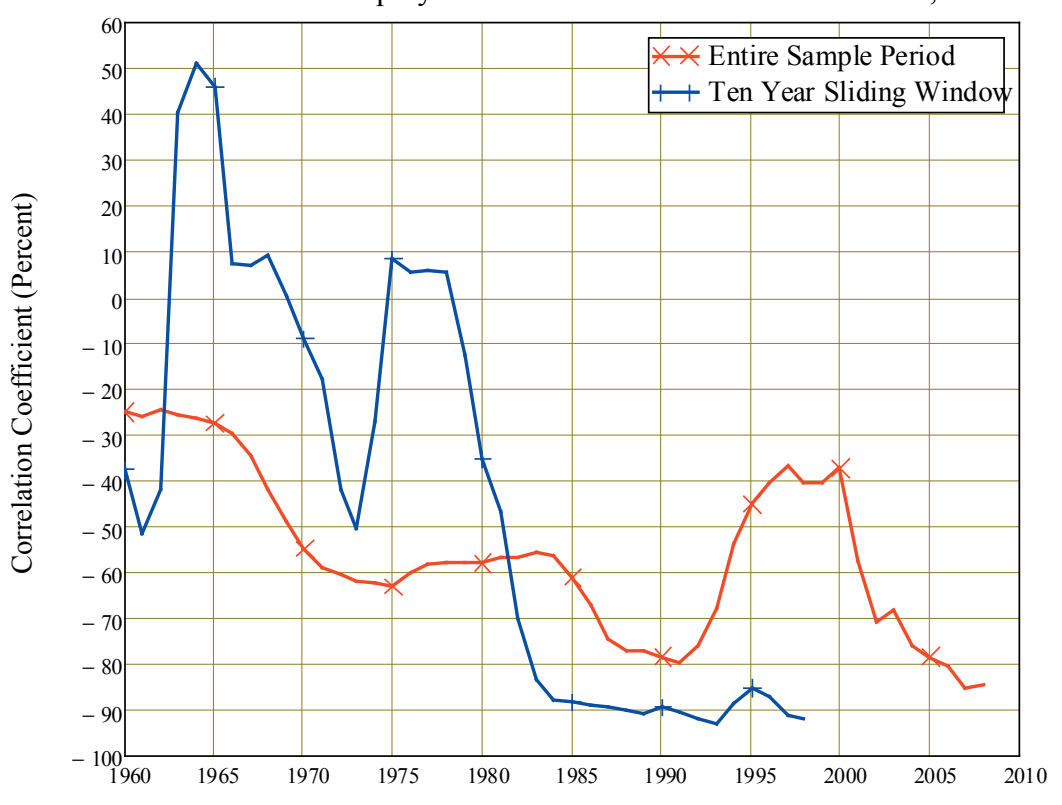

This presents a serious challenge to economic theory-even more serious than that posed by the Great Depression, the understanding of which Bernanke once described as the 'Holy Grail of macroeconomics' (Bernanke 1995,p.1). This is a challenge which Ibelieve neoclassical economics has failed. To understand the Great Depression, and the economic crisis we are now experiencing, we need to abandon neoclassicism and turn to the alternative monetary perspective of the 'Post Keynesian' school of thought. 


\section{THE FINANCIAL INSTABILITY HYPOTHESIS}

There is now a substantial academic literature on Minsky's Financial Instability Hypothesis $(F I H)$, including Minsky's own works and developments of it by a host of Post Keynesian oriented economists. A far from exhaustive list includes myself, Wynne Godley and Marc Lavoie, Randy Wray, Dimitri Papadimitriou, Jan Kregel, Thomas Palley, Éric Tymoigne and Mat Forstater; indicative papers include Keen (1995, 1999, 2000), Godley and Lavoie (2007), Wray (2007), Papadimitriou and Wray (1998), Kregel (1998), Palley (2008), Tymoigne (2007A and 2007B) and Forstater and Wray (2008). For those unfamiliar with the FIH, Keen (1995 and 2000) provides a brief verbal summary and a mathematical model, and the bibliography to this paper includes a selection of web-accessible papers by Minsky and the authors noted above.

Given the space constraints of this paper, I will omit further discussion of the FIH and turn instead to the related hypothesis in Post Keynesian economic thought, that the money supply is endogenously determined, and therefore that credit plays an essential role in economic performance.

\section{ENDOGENOUS MONEY AND FINANCIAL CRISES}

The proposition that the money supply is determined, not solely by the conventional 'money multiplier' process, but predominantly via credit-creation decisions emanating from the interplay between the industrial and financial sectors of the economy, was first championed by the American Post Keynesian economist Basil Moore (Moore 1979, 1983, 1988, 1989, 1994, 1995). Moore (and Minsky) argued that government money creation follows this with private credit creation with a lag, a proposition that found unexpected empirical support from Kydland and Prescott (1999).

There are thus two mechanisms for money creation, and in terms of the standard quantity of money and money multiplier equations, the causal sequence is reversed: increases in prices (largely but not exclusively wages) lead to increases in credit money, which subsequently force changes in either reserve requirements or base money. The credit money dog therefore wags the fiat money tail, in contrast to the textbook model of a credit money system under the control of reserve requirements and base money injections. ${ }^{11}$

In one sense, this school of thought proposes that Friedman was correct that 'money matters', but wildly wrong in his mechanism of money creation. The expansions and contractions in economic activity due to expansions and contractions in the money supply do occur, but these are due to endogenous changes in credit, rather than to the presence or absence of mythical helicopters flying over the economy dispensing dollars as in Friedman's Optimal Quantity of Money paper. During normal times with an expanding economy, growth in credit fuels economic activity, while during a 'credit-crunch', the level of endogenously-generated money in the economy falls, and this alone is sufficient to cause economic activity to contract.

11 For those unfamiliar with current monetary practice, Australia is one of six OECD nations with no reserve requirement. The USA, one of 24 that still has reserve requirements, has a zero requirement for 'time deposits and savings deposits held by entities other than individuals and households' and 'Net Eurocurrency liabilities' of American financial institutions (O’Brien 2007, p. 53-54). 
This school of thought thus gives substance to Keynes's contention that a credit economy is fundamentally different to a barter economy. Keynes's argument in the General Theory related predominantly to the difference between money and real wages in a monetary economy (Keynes 1936, p. 13). Modern Post Keynesian economics, and in particular a European variant known as Circuit Theory, argues that the distinction between a credit economy and the intellectual fiction of a barter economy is more fundamental still: in a credit economy, all exchanges are affected by the transfer of essentially valueless tokens, whereas in a barter economy, exchanges involve the transfer of commodities of equivalent value. The Circuitist deduction from this insight was that:

The only way to satisfy those three conditions is to have payments made by means of promises of a third agent, the typical third agent being nowadays a bank... any monetary payment must therefore be a triangular transaction, involving at least three agents, the payer, the payee, and the bank. Real money is therefore credit money. (Graziani 1989, p. 3).

This makes banks and credit money fundamental components of a market economy, not something that can be tacked onto a Walrasian model of barter, and it necessitates a purely monetary model of the economy. I have constructed such a model of a pure credit economy (Chapman and Keen 2005, Keen 2008, 2009), and use it here to illustrate the basic mechanisms of endogenous credit creation, and the impact of a 'credit crunch'.12

The financial dynamics of this simple pure credit economy are shown in the table in Figure 13.

The first row of the table characterises the type of variable for the modelling process: ' 1 ' represents an asset of the banking system that generates a return; ' 0 ' represents an asset that does not generate a return; and '- 1 ' represents a liability. The second row indicates the variables being modelled, which in this table are all bank accounts - respectively outstanding loans to the firm sector $F_{L}$, the bank's unlent reserves $B_{R}$, the aggregate deposits of the firm sector $F_{D}$, the aggregate income and loss accounts of the banking sector (called $B_{D}$ for consistency here), and the aggregate bank deposits of workers $W_{D}$.

Subsequent rows indicate financial transactions that normally (but not always) involve transfers between accounts:

1. The very first row is the essence of both debt and compound interest: a debt contract allows the bank to add to the outstanding debt $F_{D}$ at the rate of interest on loans $r_{L}$.

2. The second is the repayment of debt by the firm sector, which involves three steps:

a) The deduction of the sum paid from the firm sector's account $F_{D}$;

b) The transfer of that amount to the bank sector's account $B_{D}$; and

c) The accounting acknowledgement that the payment has been received by the reduction of the record of outstanding debt $F_{L}$ by the same amount;

3. The third row is interest payments at the rate $r_{D}$ on the outstanding bank account balance of the firm sector $F_{D}$;

12 This model employs a new approach to dynamic modelling, in which a model can be derived simply by adding up flow entries recorded in a 'double-entry book-keeping' table. I am still developing this methodology, and as yet have only applied it to financial flows. Physical flows are then appended as described below. 
Figure 13: Financial Flows Table

\begin{tabular}{|c|c|c|c|c|c|}
\hline "Type" & 1 & 0 & -1 & -1 & -1 \\
\hline "Account" & $\mathrm{F}_{\mathrm{L}}(\mathrm{t})$ & $\mathrm{U}_{\mathrm{R}}(\mathrm{t})$ & $\mathrm{F}_{\mathrm{D}^{(\mathrm{t})}}$ & $\mathrm{B}_{D^{(t)}}$ & $\mathrm{W}_{\mathrm{D}^{(\mathrm{t})}}$ \\
\hline "Accumulate FL" & ${ }{ }_{L} \cdot F_{L}(t)$ & 0 & 0 & 0 & 0 \\
\hline "Interest FL" & $-\left(\mathrm{r}_{\mathrm{L}} \cdot \mathrm{F}_{\mathrm{L}}(\mathrm{t})\right)$ & 0 & $-\left(\mathrm{r}_{\mathrm{L}} \cdot \mathrm{F}_{\mathrm{L}}(\mathrm{t})\right)$ & $\left(\mathrm{r}_{\mathrm{L}} \cdot \mathrm{F}_{\mathrm{L}}(\mathrm{t})\right)$ & 0 \\
\hline "Interest FD" & 0 & 0 & ${ }^{r} D^{-} F_{D}(t)$ & $-\left(\mathrm{r}_{\mathrm{D}} \cdot \mathrm{F}_{\mathrm{D}}(\mathrm{t})\right)$ & 0 \\
\hline "Wages" & 0 & 0 & $\left(\frac{1-s}{\tau_{S}}\right) \cdot \mathrm{F}_{D^{(t)}}$ & 0 & $\left(\frac{1-\mathrm{s}}{\tau_{\mathrm{S}}}\right) \cdot \mathrm{F}_{\mathrm{D}^{(\mathrm{t})}}$ \\
\hline "Interest WD" & 0 & 0 & 0 & ${ }^{-\mathrm{r}} \mathrm{D} \cdot \mathrm{W}_{\mathrm{D}^{(\mathrm{t})}}$ & $\mathrm{r}_{\mathrm{D}} \cdot \mathrm{W}_{\mathrm{D}}(\mathrm{t})$ \\
\hline "Consumption" & 0 & 0 & 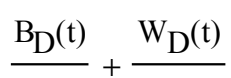 & $\left(\frac{\mathrm{B}_{\mathrm{D}^{(t)}}}{)}\right)$ & $\left(\frac{\mathrm{w}_{\mathrm{D}^{(\mathrm{t})}}}{)}\right.$ \\
\hline & & & $\tau_{\mathrm{B}} \quad \tau_{\mathrm{W}}$ & $\tau_{\mathrm{B}}$ & $\tau_{\mathrm{W}}$ \\
\hline \multirow{2}{*}{ "Repay FL" } & $F_{L}(t)$ & $\mathrm{F}_{\mathrm{L}}(\mathrm{t})$ & $\left(\mathrm{F}_{\mathrm{L}}(\mathrm{t})\right.$ & \multirow{2}{*}{0} & \multirow{2}{*}{0} \\
\hline & ${ }^{\tau} \mathrm{LRF}^{(\mathrm{t})}$ & $\tau_{\mathrm{LRF}^{(\mathrm{t})}}$ & $\tau_{\mathrm{LRF}^{(\mathrm{t})}}$ & & \\
\hline "Relend UR" & $m_{R F}(t) \cdot U_{R}(t)$ & $-\left(m_{R} F^{(t)} \cdot U_{R}(t)\right)$ & $m_{R F}(t) \cdot U_{R}(t)$ & 0 & 0 \\
\hline "New Money Firms" & $\mathrm{n}_{\mathrm{MF}}(\mathrm{t}) \cdot \mathrm{F}_{\mathrm{D}}(\mathrm{t})$ & 0 & $\mathrm{n}_{\mathrm{MF}}(\mathrm{t}) \cdot \mathrm{F}_{\mathrm{D}^{(}}(\mathrm{t})$ & 0 & 0 \\
\hline "Invest Bank Profits" & 0 & $b_{R}(t) \cdot B_{D}(t)$ & 0 & $-b_{R}(t) \cdot B_{D}(t)$ & 0 \\
\hline
\end{tabular}

4. The fourth is the payment of wages. The rate of transfer here has two components: a share (1-s) in the surplus generated by production (in Sraffa's sense rather than Marx's) where the remainder of the share goes to firms as profit; and a rate of turnover between initial expenditure on production and sales receipts $\tau_{s}$, measured in terms of fractions of a year;

5. Interest payments on workers' deposit balances;

6. Consumption (and intermediate goods purchases) by banks and workers. These are flows from accounts $B_{D}$ and $W_{D}$ to $F_{D}$ in return for flows of good moving in the opposite direction, and occur at rates $\tau_{B}$ and $\tau_{W}$ respectively - where these are again time lags expressed as fractions of a year;

7. Repayment of loans at the time-variable rate $\tau_{L R F}(t)$, which involve a transfer from the firm sector's account $F_{D}$ to the banking sectors unlent reserves account $U_{R}$. Since this is in repayment of outstanding debt, the recorded level of debt also has to be reduced by the same amount that unlent reserves rise;

8. Relending of unlent reserves at the time-variable rate $M_{R F}(t)$, which involves a transfer of money from $U_{R}$ to $F_{D}$, and a matching increase in the record of outstanding debt $F_{L}$;

9. The creation of new credit (which occurs in practice by the expansion of lines of credit, overdraft and credit card limits) by expanding FD at the time-variable rate $n_{M F}(t)$; and finally 
10. Investment of bank profits back into lending at the time-variable rate $b_{R}(t) .{ }^{13}$

To this model of financial flows I add a simple model of production, where output is the product of employed labour times labour productivity (which grows exponentially); a growing population; a money wage set by a Phillips curve relation; and prices set by a lagged adjustment to the gap between demand and supply (a 'neoclassical' price function, but phrased dynamically as opposed to the standard neoclassical approach of comparative statics). The entire system is as shown in Figure 14. Parameter values and definitions are given in the Appendix.

Figure 14: System equations

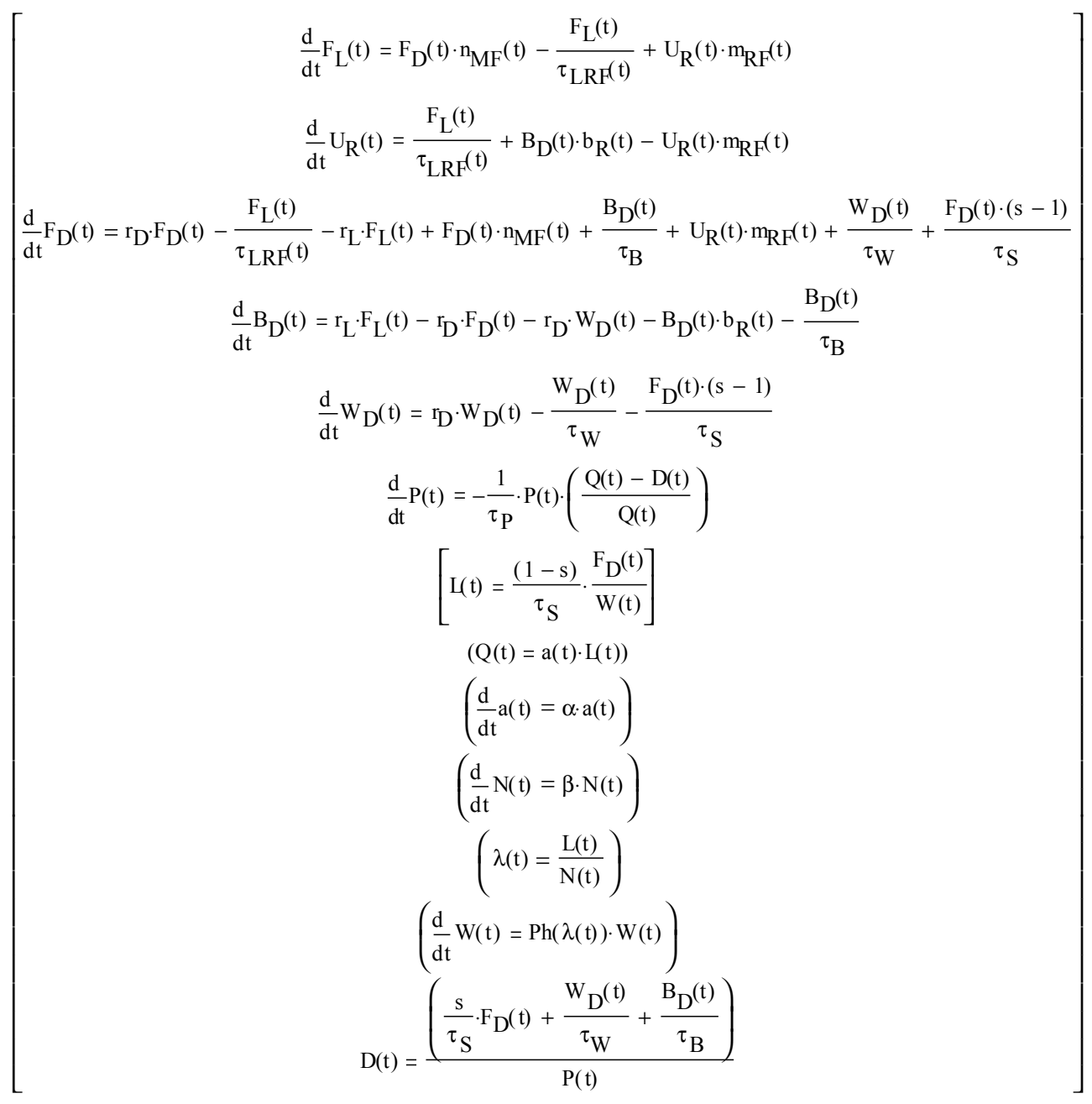

13 This row could be dropped from the model without dramatically affecting the model's behaviour (as could row 5 for interest payments on workers' accounts), but is included to generate the real-world result that the level of debt exceeds the level of money (which is the sum of the deposit accounts in this model). 
The figures below show simulations of the model with a 'credit crunch' introduced at $\mathrm{t}=30$ years by multiplying the time-variable parameters in the model by 0.32 : the firm sector's loan repayment horizon drops from 20 to 6.4 years, the rate of new money creation drops from $10 \%$ per annum to $3.2 \%$, and likewise for the other two time-variable parameters. ${ }^{14}$ The impact of this simulated credit crunch on the model economy is dramatic-comparable to the impact of the Great Depression on the US economy.

The driving force is a collapse in the amount of money circulating in the model and a corresponding rise in unlent reserves, as is evident in Figure 15.

\section{Figure 15}

\section{Aggregate Bank Deposits \& Reserves}

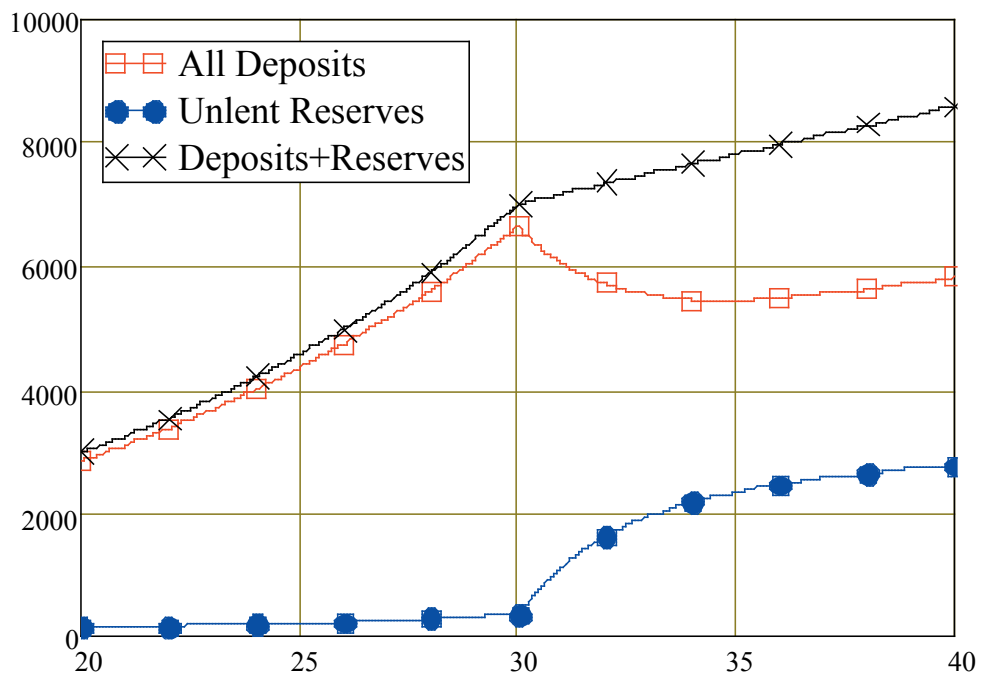

The table in Figure 15 summarises the overall dynamics of the economy due to the credit crunch, while the subsequent figures illustrate the time paths of important system variables. ${ }^{15}$ Some of the key outcomes of the model that mimic the actual experience of the Great Depression are that the fall in nominal debt levels does not cause a fall in the debt to GDP ratio (the first and last lines of the table); deflation is triggered by the crisis; employment falls dramatically; and substantial falls in money wages result in a rise in real wages, because the fall in prices more than exceeds the fall in money wages.

14 I could also have made consumption parameters time-variable, but restricted the variability to financial flow parameters for the sake of simplicity.

15 I do not contend that a credit crunch is the entire reason for the Great Depression, since the model currently omits the excessive debt levels, the de-leveraging process and the Ponzi financing that are a major clearly part of a real-world Depression. However the size of the 'credit crunch' has been chosen so as to illustrate the potential impact of a change in financial flows on economic performance. 
Figure 16: Summary of impact of credit crunch

\begin{tabular}{|l|r|r|r|r|}
\hline \multicolumn{1}{|c|}{ Variable } & Value at Crunch & $\begin{array}{r}\text { Value 5 } \\
\text { later }\end{array}$ & \multicolumn{1}{c|}{ Change } & \multicolumn{1}{c|}{ Ratio } \\
\hline Firm Loan & $\$ 6,713$ & $\$ 5,602$ & $-16.54 \%$ & 0.83 \\
\hline Unlent Reserves & $\$ 346$ & $\$ 2,344$ & $576.88 \%$ & 6.77 \\
\hline Firm Deposit & $\$ 5,934$ & $\$ 4,839$ & $-18.46 \%$ & 0.82 \\
\hline Bank Deposit & $\$ 210$ & $\$ 215$ & $2.22 \%$ & 1.02 \\
\hline Worker Deposit & $\$ 501$ & $\$ 410$ & $-18.20 \%$ & 0.82 \\
\hline Money (sum Deposits) & $\$ 6,645$ & $\$ 5,463$ & $-17.78 \%$ & 0.82 \\
\hline Velocity of Money (Deposits only) & 3.45 & 3.69 & $7.09 \%$ & 1.07 \\
\hline Velocity of Money (including Unlent Reserves) & 3.27 & 2.58 & $-21.16 \%$ & 0.79 \\
\hline Price Level & 31.81 & 29.92 & $-5.94 \%$ & 0.94 \\
\hline Employment & 395 & 335 & $-15.30 \%$ & 0.84699 \\
\hline Real Output & 720 & 674 & $-6.39 \%$ & 0.93607 \\
\hline Real Demand & 752 & 654 & $-12.96 \%$ & 0.87 \\
\hline Real Demand Gap & 32 & -19 & $-160.82 \%$ & -0.60822 \\
\hline Nominal Output & 22892 & 20154 & $-11.96 \%$ & 0.88044 \\
\hline Nominal Demand & $\$ 23,909$ & $\$ 19,573$ & $-18.14 \%$ & 0.82 \\
\hline Nominal Demand Gap & $\$ 1,017$ & $-\$ 582$ & $-157.21 \%$ & -0.57 \\
\hline Labour Productivity & 1.82 & 2.01 & $10.52 \%$ & 1.11 \\
\hline Population & 401 & 443 & $10.52 \%$ & 1.11 \\
\hline Employment Rate & $98.5 \%$ & $75.5 \%$ & $-23.36 \%$ & 0.77 \\
\hline Unemployment Rate & $1.5 \%$ & $24.5 \%$ & $1562.81 \%$ & 16.63 \\
\hline Money Wage & $\$ 33.05$ & $\$ 31.82$ & $-3.72 \%$ & 0.96 \\
\hline Real Wage & 1.04 & 1.06 & $2.36 \%$ & 1.02 \\
\hline Debt/Output Ratio & $29.32 \%$ & $27.80 \%$ & $-5.21 \%$ & 0.95 \\
\hline
\end{tabular}

Real output and employment fall substantially, as occurred during the Great Depression. Prices fell too, again replicating the historical experience, and rather than solving the problem in a 'neoclassical' way, the falling price level exacerbated the problem to some extent by undermining the attempts by the firm sector to reduce its debt level (bearing in mind that one key parameter change was a reduction in the firm sector's time lag for debt repayment from 20 years to 6.4 years).

Figure 17

Real Output and Employment

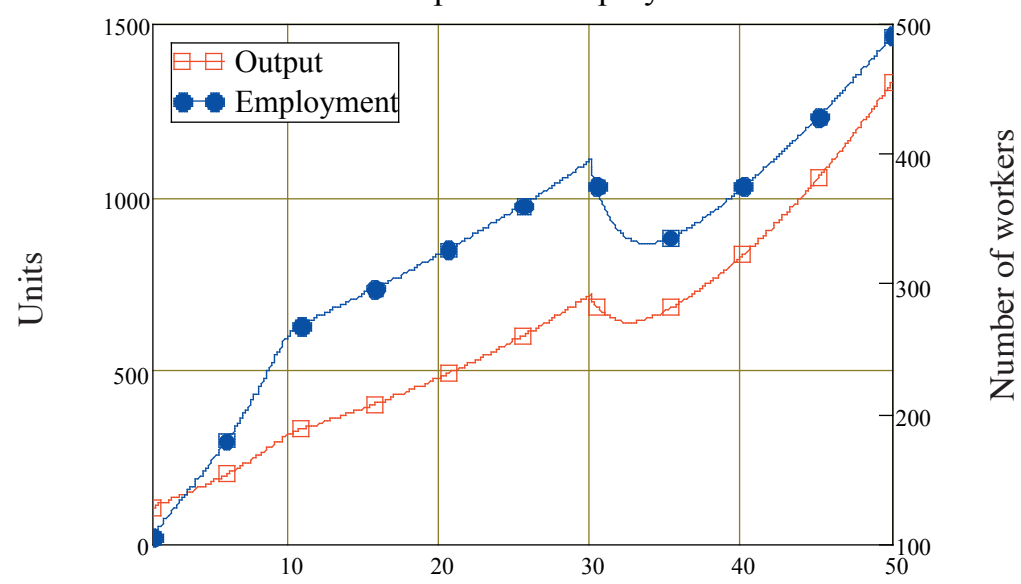


The unemployment rate rises dramatically, though its rise eventually stops and unemployment then slowly falls.

Figure 18

Unemployment Rate

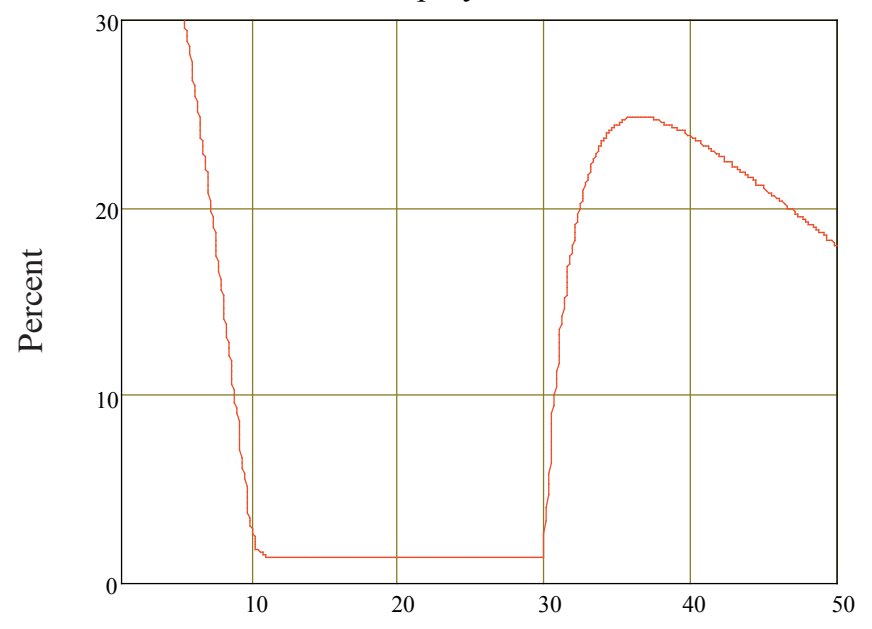

The price level falls substantially, which, along with the fall in real output, explains the paradox that the debt to output ratio rises even though the nominal level of debt falls - Fisher's Paradox.

Figure 19

Price Level

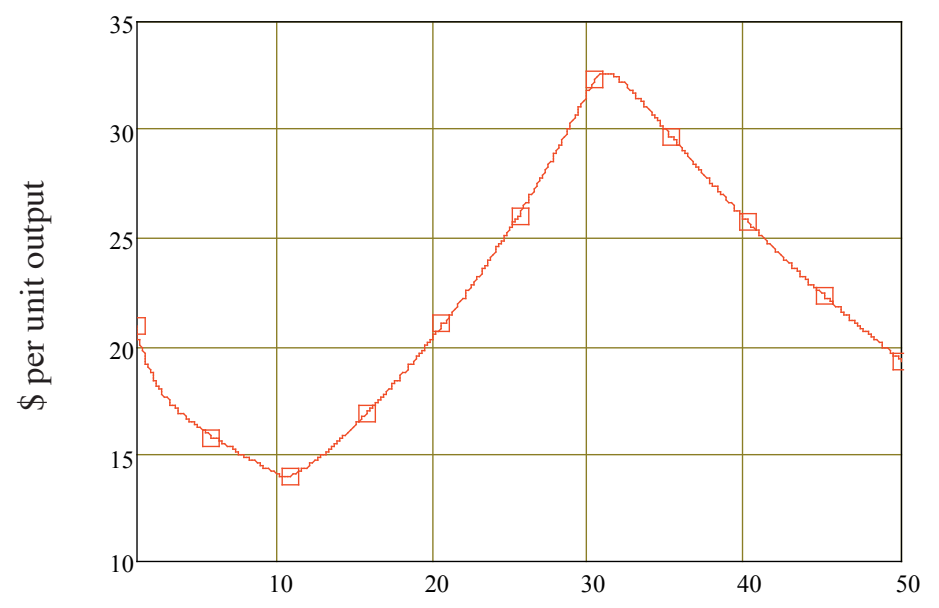

A key 'emergent property' of the simulation was that a substantial fall in the nominal wage had almost no impact on the real wage. This was unexpected but historically relevant, given Keynes's arguments against cutting nominal wages during the Depression on precisely this basis (Keynes 1936, Chapter 19). Nominal wages fall in this model as unemployment 
rises - but the fall in nominal wages barely stops the advance of real wages, since the fall in the price level exceeds the fall in wages.

Figure 20

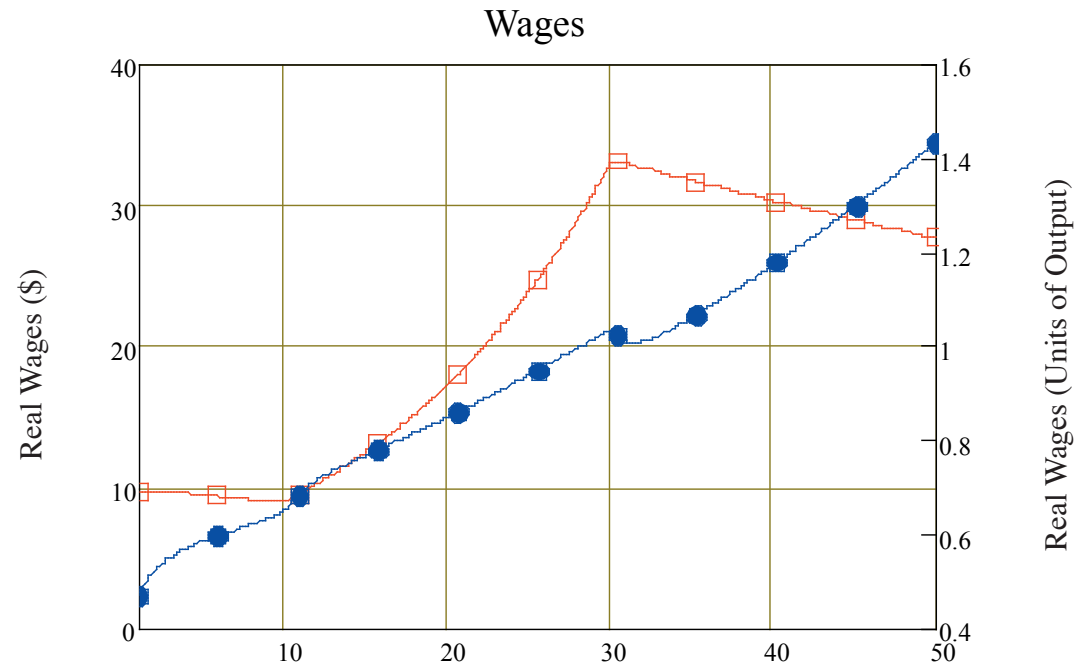

Figure 21 shows a transient drop in the real wage when the crisis begins, which then gives way to a sustained rise in the real wage from that time on, regardless of a substantial rate of unemployment and a continuous fall in nominal wages.

Figure 21: Wage dynamics at a credit crunch - falling nominal and rising real wages

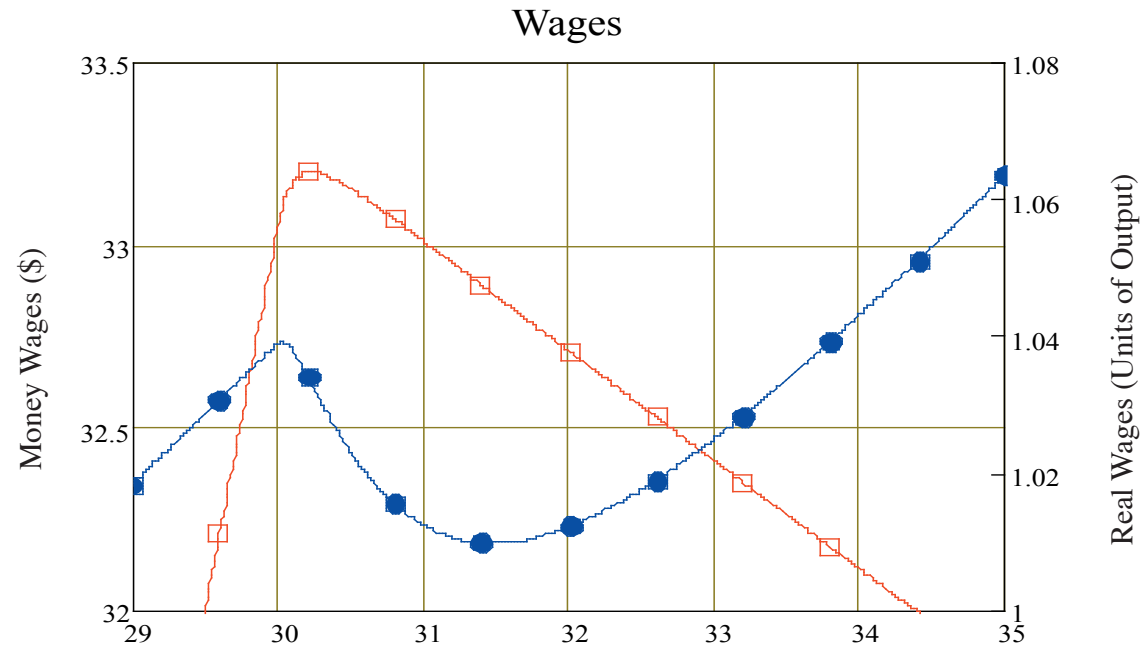




\section{CONCLUSION}

There are good empirical and theoretical grounds on which to expect that the proposed bailouts will fail to arrest the decline of the US and global economies into a Depression.

If so, what are the policy alternatives to bailouts, pump-priming, and the printing press? Obviously we have failed in the ultimate policy, to, as Minsky put it, 'establish and enforce a 'good financial society' in which the tendency by businesses and bankers to engage in speculative finance is constrained' (Minsky 1977, p. 16) - though that clearly has to be a post-GFC objective.

Recovery from the Depression the GFC will probably cause requires direct attention to the cause of the crisis itself-excessive private debt accumulated during a sequence of Ponzifinanced speculative bubbles.

The pillars of the American banking system in particular acted as direct descendants of Charles Ponzi, ${ }^{16}$ and they have bankrupted the American financial system as effectively as Ponzi bankrupted himself. The system should be temporarily nationalised, and during that (potentially lengthy) interim, compelled to do what should be the main activity of financeprovide working capital for non-financial firms.

The debt must be reduced, whether by monetary means (reflation) or outright debt moratoria. On the former front, while I doubt the effectiveness of Bernanke's printing press in causing inflation (and Japan's attempt to do likewise in 2002 was a dismal failure), an effective way to cause inflation would be to increase money wages, with the direct objective of causing firms to increase their prices to compensate.

The last suggestion is, of course, heresy in terms of conventional neoclassical economic theory, which brings me to the elephant in the economic living room: there are compelling reasons why this crisis should lead to a drastic revision in economic thought as well. It is no exaggeration to say that the naïve faith in deregulated financial markets engendered by neoclassical economics played a large role in the institutional changes and regulatory action (and inaction) that gave rise to this crisis. It is also patently obvious that neoclassically-trained economists were caught completely unawares by the crisis, despite - or rather, because of - the sophisticated mathematical forecasting models that their predecessors in the 1920s lacked, but which in turn lacked any appreciation of the actual financial dynamics of a credit-driven economy.

My favourite instance of this is the Panglossian confidence expressed in the global economy's future by the 2007 OECD Economic Outlook, which was published a mere two months before the crisis began in earnest:

the current economic situation is in many ways better than what we have experienced in years. Against that background, we have stuck to the rebalancing scenario. Our central forecast remains indeed quite benign: a soft landing in the United States, a strong and sustained recovery in Europe, a solid trajectory in Japan and buoyant activity in China and India. In line with recent trends, sustained growth in OECD economies would be underpinned by strong job creation and falling unemployment. (Cotis 2007, p. 7)

16 See http://en.wikipedia.org/wiki/Charles_Ponzi for an overview and Zukoff (2005) for an excellent and compelling history. 
We must do better than this in future. If this crisis does turns into a Depression, then the non-monetary, equilibrium-obsessed, ahistorical practices that have come to dominate our profession must also be abandoned.

\section{APPENDIX}

\begin{tabular}{|l|l|l|l|}
\hline Variable or Parameter & Symbol & Initial value & Value at Crunch \\
\hline Firm Loan & $\mathrm{F}_{\mathrm{L}}$ & 100 & Dynamic \\
\hline Unlent Reserves & $\mathrm{U}_{\mathrm{L}}$ & 100 & Dynamic \\
\hline Firm Deposit & $\mathrm{F}_{\mathrm{D}}$ & 100 & Dynamic \\
\hline Bank Deposit & $\mathrm{B}_{\mathrm{D}}$ & 30 & Dynamic \\
\hline Worker Deposit & $\mathrm{W}_{\mathrm{D}}$ & 300 & Dynamic \\
\hline Price Level & $\mathrm{P}$ & 20 & Dynamic \\
\hline Labour Force & $\mathrm{L}$ & 200 & Dynamic \\
\hline Output & $\mathrm{Q}$ & 200 & Dynamic \\
\hline Labour productivity & $\mathrm{a}$ & 1 & Dynamic \\
\hline Labour productivity growth rate & $\alpha$ & $2 \%$ & No Change \\
\hline Population & $\mathrm{N}$ & 220 & Dynamic \\
\hline Population growth rate & $\beta$ & $2 \%$ & No Change \\
\hline Employment rate & $\gamma$ & $90.9 \%$ & Dynamic \\
\hline Money Wages & $\mathrm{W}$ & 10 & Dynamic \\
\hline Demand & $\mathrm{D}$ & 100 & Dynamic \\
\hline Firm sector share of surplus & $\mathrm{s}$ & $45 \%$ & No Change \\
\hline Time lag between production and sales & $\tau_{\mathrm{S}}$ & $1 / 4$ year & No Change \\
\hline Time lag in loan repayment & $\tau_{\mathrm{LRF}}$ & 20 years & 6.4 years \\
\hline New money creation rate & $\mathrm{n}_{\mathrm{M}}$ & $10 \%$ & $3.2 \%$ \\
\hline Bank reinvestment of profits rate & $\mathrm{b}_{\mathrm{R}}$ & $20 \%$ & $6.4 \%$ \\
\hline Money relending rate & $\mathrm{m}_{\mathrm{RF}}$ & $100 \%$ & $32 \%$ \\
\hline Rate of interest on loans & $\mathrm{r}_{\mathrm{L}}$ & $5 \%$ & No Change \\
\hline Rate of interest on deposits & $\mathrm{r}_{\mathrm{D}}$ & $1 \%$ & No Change \\
\hline Banker consumption time lag & $\tau_{\mathrm{B}}$ & 1 year & No Change \\
\hline Worker consumption time lag & $\tau_{\mathrm{W}}$ & 2 weeks & No Change \\
\hline Price adjustment lag & $\tau_{\mathrm{P}}$ & 1 year & No Change \\
\hline $\begin{array}{l}\text { Phillips curve exponential relation } \\
\text { generalized exponential function fitted } \\
\text { to Phillips's UK 1861-1957 data) }\end{array}$ & $\mathrm{P}_{\mathrm{h}}(\lambda)$ & $(0.009197) . e .527$ & \\
\hline & & $\lambda-0949)$ & \\
\hline & & & 0.009197 \\
\hline
\end{tabular}

\section{REFERENCES}

Bernanke, B. (1995). The Macroeconomics of the Great Depression: A Comparative Approach, Journal of Money, Credit, and Banking. 27: 1-28.

Bernanke, B. (2002A). Remarks by Governor Ben S. Bernanke At the Conference to Honor Milton Friedman, University of Chicago, Chicago, Illinois November 8, 2002 On Milton Friedman's Ninetieth Birthday (http://www.federalreserve.gov/boarddocs/speeches/2002/20021108/default.htm)

Bernanke, B. (2002B). (Remarks by Governor Ben S. Bernanke Before the National Economists Club, Washington, D.C., November 21, 2002, 'Deflation: Making Sure 'It' Doesn’t Happen Here, http:// www.federalreserve.gov/boardDocs/speeches/2002/20021121/default.htm). 
Bernanke, B. and M. Gertler(2001). Quantitative Policy Implications Of New Normative Macroeconomic Research: Should Central Banks Respond To Movements In Asset Prices?, AEA Papers And Proceedings pp. 253-257.

Chapman, B. and S. Keen (2006). Hic Rhodus, Hic Salta! Profit in a dynamic model of the Monetary Circuit, Storia del Pensiero Economico. 2-2006: 139-156.

Cotis, J.P.(OECDChief Economist) (2007). Editorial: Achieving Further Rebalancing, OECD Economic Outlook. 81: 7-9.

Godley, W. and M. Lavoie (2007). Monetary Economics: An Integrated Approach to Credit, Money, Income, Production and Wealthh. New York: Palgrave Macmillan.

Fisher, C. and C. Kent (1999). Two Depressions, One Banking Collapse, Reserve Bank of Australia Research Discussion Papers, RDP1999-06, http://www.rba.gov.au/PublicationsAndResearch/RDP/ RDP1999-06.html

Fisher I. (1933). The debt-deflation theory of great depressions, Econometrica. 1: 337-357.

Forstater, M. and L.R. Wray (2008). In: (eds.) Keynes for the Twenty-First Century: The Continuing Relevance of the General Theory. New York: Palgrave Macmillan.

Friedman, M. and A.J. Schwartz (1971). Monetary History of the United States, 1867-1960, Princeton: Princeton University Press.

Graziani A. (1989). The Theory of the Monetary Circuit, Thames Papers in Political Economy, Spring, pp. 1-26. Reprinted in: (eds.) M. Musella and C. Panico (1995), The Money Supply in the Economic Process. Aldershot: Edward Elgar.

Keen, S. (1995). Finance and economic breakdown: modelling Minsky's Financial Instability Hypothesis, Journal of Post Keynesian Economics. 17: 607-635.

Keen, S. (1999). The nonlinear dynamics of debt deflation, Complexity International. 6.

Keen, S. (2000). The nonlinear economics of debt deflation. In: (eds.) W. Barnett, C. Chiarella, S. Keen, R. Marks, H. Schnabl. Commerce, Complexity and Evolution. Cambridge: Cambridge University Press, p. 83-110.

Keen, S. (2008), Keynes's 'revolving fund of finance' and transactions in the Circuit. In: (ed.) R. Wray, The $60^{\text {th }}$ Anniversary of Keynes's General Theory. Aldershot: Edward Elgar.

Keen, S. (2009), The non-conservation of money. Physica A (forthcoming).

Kregel, J.A. (1998). Aspects of a Post Keynesian Theory of Finance, Journal of Post Keynesian Economics. 21: 111-33.

Kydland, F.E., and Prescott, E.C. (1999). Business Cycles: Real Facts and a Monetary Myth, Federal Reserve Bank of Minneapolis Quarterly Review. 23: 25-31.

Minsky, H., (1969). Financial Model Building and Federal Reserve Policy: Discussion, Journal of Finance. 24: 295-97.

Minsky, H. (1977). The Financial Instability Hypothesis: An Interpretation of Keynes and an Alternative to 'Standard' Theory, Nebraska Journal of Economics and Business. 16: 5-16.

Minsky, H. (1980A). Capitalist Financial Processes and the Instability of Capitalism, Journal of Economic Issues. 14: 505-23.

Minsky, H. (1980B). Money, Financial Markets, and the Coherence of a Market Economy, Journal of Post Keynesian Economics. 3: 21-31.

Minsky, H. (1982). Can 'It' Happen Again? A Reprise, Challenge. 25: 5-13.

Minsky, H. (1985A). Money and the Lender of Last Resort, Challenge. 28: 12-18.

Minsky, H. (1985B). The Legacy of Keynes, Journal of Economic Education. 16: 5-15.

Minsky, H. (1986). The Evolution of Financial Institutions and the Performance of the Economy, Journal of Economic Issues. 20: 345-53.

Minsky, H. (1989). Economic Implications of Extraordinary Movements in Stock Prices: Comments, Brookings Papers on Economic Activity. 1989: 173-82.

Minsky, H. (1995A). Financial Factors in the Economics of Capitalism, Journal of Financial Services Research. 9: 197-208. 
Minsky, H. (1995B). Financial Markets and Economic Instability, 1965-1980, Nebraska, Journal of Economics and Business. 20: 5-16.

Minsky, H. (1995C). Longer Waves in Financial Relations: Financial Factors in the More Severe Depressions II, Journal of Economic Issues. 29: 83-96.

Minsky, H. (1998). Back from the Brink, Challenge. 31: 22-28.

Moore, B.J. (1979). The Endogenous Money Stock, Journal of Post Keynesian Economics. 2: 49-70.

Moore, B. J. (1983). Unpacking the Post Keynesian Black Box: Bank Lending and the Money Supply, Journal of Post Keynesian Economics. 5: 537-56.

Moore, B.J. (1988). Unpacking the Post-Keynesian Black Box: Wages, Bank Lending and the Money Supply. In (ed.) P. Arestis, Post-Keynesian monetary economics: New approaches to financial modeling. Aldershot: Edward Elgar: 122-51.

Moore, B.J., (1989). A Simple Model of Bank Intermediation, Journal of Post Keynesian Economics. 12: $10-28$.

Moore, B.J., (1994). The Demise of the Keynesian Multiplier: A Reply to Cottrell, Journal of Post Keynesian Economics. 17: 121-33.

Moore, B.J. (1995). Unpacking the Post Keynesian Black Box: Bank Lending and the Money Supply. In: (eds.) M. Musella and C. Panico, The money supply in the economic process: A post Keynesian perspective. Aldershot: Edward Elgar: 365-84.

O'Brien, Y.C. (2007). Reserve requirement systems in OECD countries, Board of Governors of the Federal Reserve System (U.S.), Finance and Economics Discussion Series: 2007-54.

Palley, T.I. (2008). Keynesian Models of Deflation and Depression Revisited, Journal of Economic Behavior and Organization. 68: 167-77.

Papadimitriou, D.B. and L.R. Wray (1998). The Economic Contributions of Hyman Minsky: Varieties of Capitalism and Institutional Reform, Review of Political Economy. 10: 199-225.

Tymoigne, E, (2007A). A Hard-Nosed Look at Worsening U.S. Household Finance, Challenge. 50: 88-111.

Tymoigne, E. (2007B). Improving Financial Stability: Uncertainty versus Imperfection, Journal of Economic Issues. 41: 503-10.

Tymoigne, E. and L.R. Wray (2006). Money: An Alternative Story. In (eds.) P. Arestis and M. Sawyer, A Handbook of Alternative Monetary Economics. Cheltenham: Edward Elgar Publishers: 1-16.

Wray, L.R. (2007). A Post Keynesian View of Central Bank Independence, Policy Targets, and the Rules versus Discretion Debate, Journal of Post Keynesian Economics. 30: 119-41.

Zuckoff, M. (2005). Ponzi's Scheme: The True Story of a Financial Legend. New York: Random House. 